\title{
Relevance of Legal Certainty In Criminal of Consent In The Eradication Of Corruption Law
}

\author{
Haryono*) and Bambang Tri Bawono**) $^{* *}$ \\ *) Resort Police of Semarang, E-mail: sabharagrobogan@gmail.com \\ **) Faculty of Law Universitas Islam Sultan Agung (UNISSULA) Semarang
}

\begin{abstract}
This study aims to analyze and determine the construction of evil consensus in corruption in Indonesia; legal weaknesses in cases of criminal conspiracy in corrupt criminal acts as well as reconstruction of evil conspiracy in criminal acts of corruption based on progressive law. The research uses a sociological juridical approach. Based on the research conducted, it was found the fact that the implementation of law enforcement in cases of conspiracy related to corruption is currently not fair, this is due to the unclear elements in the criminal act of conspiracy in corruption cases so that existing law enforcement is based on political interests, where the authorities will be able to looking for a way out of the snares of Article 15 of Act No. 31 of 1999 Jo. Act No. 20 of 2001 concerning the Eradication of Criminal Acts of Corruption, while parties who do not have the authority to power will not be able to escape the snares of Article 15 of Act No. 31 of 1999 Jo. Act No. 20 of 2001 concerning the Eradication of Corruption Crimes.
\end{abstract}

Keywords: Legal Certainty, Evil Conspiracy, Corruption Crime

\section{Introduction}

Legal problems related to conspiracy in criminal acts of corruption arise due to the lack of clear and firm understanding of the meaning of evil conspiracy itself, causing multiple interpretations. The implementation of the meaning and substance of evil consensus in corruption has not been fully reflected in the laws and regulations so that both state administrators and law enforcers find it difficult to carry out these functions of authority. ${ }^{1}$ For example in the case of Anggodo Widjojo, in that case on August 31, 2010, the Panel of Judges of the Corruption Court stated that Anggodo was legally and convincingly proven guilty of committing a criminal act of corruption by imposing a sentence of 4 (four) years in prison and a fine of IDR 150 million subsidiary 3 (three) months in prison. The chairman of the panel of judges, Tjokorda Rai Suwamba, said that only the first indictment, namely Article 15 in conjunction with Article 5 paragraph (1) letter a of Act No. 31 of 1999 concerning the Eradication of Corruption Crimes in conjunction with Article 55 paragraph (1) of the 1st Criminal Code, was proven, namely every person commits an evil conspiracy to give or promise something to a civil servant or state administrator with the intention of the civil servant or state

\footnotetext{
1Ibnu Suka, Gunarto, and Umar Ma'ruf, "Peran Dan Tanggung Jawab Polri Sebagai Penegak Hukum Dalam Melaksanaan Restorative Justice Untuk Keadilan Dan Kemanfaatan Masyarakat”, dalam Jurnal Hukum Khaira Ummah Vol. 13. No. 1 March 2018, p. 115-116.
} 
administrator doing or not doing something in an office that is contrary to the obligation to be fulfilled. ${ }^{2}$

The same case also happened to the defendant Mochtar Mohamad, in that case Mochtar Mohamad who is the Mayor of Bekasi City was charged with Article 5 paragraph (1) letter a in conjunction with Article 15 of Act No. 31 of 1999 concerning Eradication of Corruption Crimes as amended by Act No. 20 of 2001 concerning Amendments to Act No. 31 of 1999 concerning Eradication of Criminal Acts of Corruption. The evil conspiracy carried out by Mochtar Mohamad was together with Tjandra Utama Effendi as the Regional Secretary of the City of Bekasi who carried out an evil conspiracy to commit a criminal act of corruption, namely giving money amounting to IDR 500,000,000,- (five hundred million rupiah) to the ADIPURA Assessment Team, among others, to Melda Mardalina as a Civil Servant at the Ministry of Environment. ${ }^{3}$

His actions made the Panel of Judges declare that Mochtar Mohamad was proven guilty of corruption and sentenced him to imprisonment for 6 (six) years and a fine of IDR 300,000,000,- (six hundred million rupiah), provided that if the fine is not paid, the defendant is subject to a substitute sentence of imprisonment for 6 (six) months. The Panel of Judges considered that the actions of the defendant Tjandra Utama Effendi and the Heads of SKPD were clearly a malicious conspiracy, because there were 2 (two) or more people who agreed to commit a criminal act of corruption in the form of giving money to Civil Servants to do something in their position, namely increasing the value for get the Adipura award,

In addition, another case of conspiracy to commit criminal acts of corruption was carried out by members of the DPR on behalf of Drs. Setya Novanto. In connection with the evil conspiracy in Article 15 of Act No. 31 of 1999 concerning the Eradication of Criminal Acts of Corruption, there has been a Constitutional Court Decision Number 21/PUU-XIV/2016 dated 07 September 2016. The case relates to the applicant Setya Novanto, who at that time was a member of the DPR, where according to the applicant himself, he has been investigated in an investigation into alleged criminal acts of corruption, conspiracy, or attempted corruption in the extension of the contract of PT. Freeport Indonesia. Because the applicant is suspected of having committed a special crime in the form of conspiracy to end corruption in his meeting with the President Director of PT. Freeport Indonesia at that time, Maroef Sjamsuddin and entrepreneur Muhammad Riza Chalid in June 2015. So that the applicant is positioned as the perpetrator of evil conspiracy together with Muhammad Riza Chalid to commit a criminal act of corruption related to the extension of the license or contract of PT. Freeport Indonesia.

The Constitutional Court considers that all provisions in Article 2, Article 3, Article 5 to Article 14 of the Corruption Law are qualitative criminal acts that require the quality of a person either as a civil servant or a state official to fulfill the elements of the offense. Therefore, the Constitutional Court is of the opinion that Article 15 in conjunction with Article 12 letter e of Act No. 31 of 1999

2thttp://www.bbc.com/indonesia/berita_indonesia/2010/08/100831_anggodovonis.shtml, accessed on January 2, 2021

${ }^{3}$ Supreme Court Decision Number 2547 K/Pid.Sus/2011. 
concerning the Eradication of Criminal Acts of Corruption as amended by Act No. 20 of 2001 concerning Amendments to Act No. 31 of 1999 concerning Eradication Corruption crime can only be applied to an agreement between 2 (two) or more people who have special qualities as civil servants or state officials as referred to in Article 1 point 1 and Article 1 point 2.4

Although it is not explicitly stated in the decision of the Constitutional Court, it is clear that what is meant here is that businessman Muhammad Riza Chalid who participated with the applicant in his meeting with the President Director of PT. Freeport Indonesia, is a person who does not meet the special qualities as a Civil Servant (PNS) or state official, so that the applicant cannot be said to have committed malicious conspiracy. Based on these considerations, the Constitutional Court in its decision has decided, among others, to grant the applicant's request in its entirety, (2) The phrase "evil consensus" in Article 15 of Act No. 31 of 1999 concerning Eradication of Criminal Acts of Corruption as amended by Act No. 20 of 2001 concerning Amendments to Act No. 31 of 1999 concerning Eradication of Criminal Acts of Corruption ( The State Gazette of the Republic of Indonesia of 2001 Number 134, Supplement to the State Gazette of the Republic of Indonesia Number 4150) does not have binding legal force as long as it is not interpreted, "Evil consensus is when two or more people who have the same qualities agree to commit a criminal act". This decision shows that the Constitutional Court has added the word "having the same quality as agreeing to commit a criminal act",

In connection with the Constitutional Court Decision Number 21/PUUXIV/2016 dated September 7, 2016, according to the author, the definition of the meaning of evil consensus still causes multiple interpretations, moreover the meaning of evil consensus in relation to corruption is not included in the chapter of the law of corruption itself, thus causing legal weakness for the perpetrators of corruption. Evil consensus does have a number of weaknesses related to the difficulty of the evidentiary process, especially with regard to the element of agreement. The first opinion states that there must be a clear agreement between the briber and the briber or extortionist and the extorted. While other opinions stated that the agreement was not needed.

The concept of "agreement" needs to be proven by the existence of a meeting of mind that does not require an agreement between the bribed and the briber or the blackmailer and the extorted. However, with the agreement of 2 (two) or more people to ask for something without having to have the consent of the one who will bribe or who will be extorted, it is strong enough. It was also emphasized that the meeting of mind does not need words that signify explicit agreement but suffices with body language and sentences that indirectly indicate an agreement. The rationale used is Article 55 of the Criminal Code. Besides that,

Based on the above background, the authors are interested in researching and analyzing further about the meaning of evil consensus in the crime of corruption so that it is no longer multi-interpreted so that a reconstruction is

${ }^{4}$ Fatkhurohman and Nalom Kurniawan, "Pergeseran Delik Korupsi dalam Putusan Mahkamah Konstitusi Nomor 25/PUU-XIV/2016”, Jurnal Konstitusi, Volume 14, Number 1, March 2017, p. 4-5. 
needed. Where basically the crime of corruption is an extraordinary crime that is detrimental to the state and social community. ${ }^{5}$

\section{Research Methods}

The type of research used in this study is a sociological juridical legal research type. The approach uses sociological juridical, the specification in this writing is analytical descriptive. Methods of collecting data by means of field studies and literature studies. Methods of data analysis using qualitative methods.

\section{Results and Discussion}

\subsection{Construction of Evil Conspiracy in Criminal Law Politics in Indonesia}

It has been explained above that the arrangements related to conspiracy in corruption are generally regulated in Articles 88, 110, 116, 125, 139c, 164, 457 and 462 of the Criminal Code. Among these articles, Article 88 only provides an authentic interpretation of "samenspanning" (malicious conspiracy); Article 164 deals with people who know that there is an evil conspiracy, so the person concerned himself is not involved in the evil conspiracy; while articles 457 and 462 are related to offenses that begin with consensus, so their activities do not only reach consensus but are continued with actions.

In its development, evidence related to the agreement in the criminal act of conspiracy in the criminal act of corruption is not easy to do. This is further complicated by the Constitutional Court Decision Number 25/PUU-XIV/2016 which removes the phrase "can" in actions that have the potential to harm state finances. The abolition of the phrase clearly results in a new act that has the potential to result in criminal acts of corruption not being punished. So to be able to declare someone has committed corruption, it must be proven clearly related to economic and state financial losses.

This can be seen in the case of Syahril Djohan and Haposan Hutagalung in the Arowana case where the Prosecutor charged Syahril Djohan with Article 5 paragraph (1) letter a of the PTPK Jo Law. Article 55 paragraph (1) of the 1st Criminal Code, a subsidiary of Article 13 of the PTPK Law Jo. Article 55 paragraph (1) of the 1st Criminal Code, the Second Indictment, namely Article 5 paragraph (1) letter a of the PTPK Law, Article 55 paragraph (1) of the 1st Criminal Code, Article 15 of the PTPK Law, Article 88 of the Criminal Code Jo. Article 13 of the PTPK Law, Article 15 of the PTPK Law, and Article 88 of the Criminal Code. In that case the Prosecutor argued that Syahril Djohan had conspired together to commit a criminal act of corruption, but the judge's opinion was different, according to judge Syaril Djohan only attended the meeting and was in a listening capacity and did not take any further action. ${ }^{6}$

In the Arowana case, it is clear that the evidence in criminal law in the form of witness statements, documents, statements of the defendant, electronic

\footnotetext{
${ }^{5}$ Rian Prayudi Saputra, Perbandingan Hukum Pidana Indonesia Dengan Inggris, Jurnal Pahlawan, Volume 3 Nomor 1, 2020, p. 54.

${ }^{6}$ http://repository.unair.ac.id/94028/4/4.\%20BAB\%20I\%20.pdf, Retrieved 20 March 2021.
} 
evidence is not able to prove the agreement as the basis for the existence of evil conspiracy in corruption cases. However, in contrast to the Setya Novanto case, in this case Setya Novanto filed a lawsuit against Article 15 of Act No. 31 of 1999 Jo. Act No. 20 of 2001 concerning the Eradication of Corruption, in which Setya Novanto through his attorney stated that Article 15 has a weakness in the form of easy interpretation of evil conspiracy acts in the Corruption Court. This is due to the multi-interpretation of the agreement, while in this case, according to Setya Novanto, he cannot be proven to have committed a malicious conspiracy because he is not a high-ranking officer of PT. FREEPORT is able to determine whether divestment will be carried out, so according to him and his legal counsel the charge of conspiracy against him is a putative offense, namely an offense that is suspected to be a criminal offense but is not a criminal offense. ${ }^{7}$ However, Setya Novanto was still found guilty with evidence of recordings of Setnov's conversations with Freeport officials.

Based on the various explanations above, it is clear that the implementation of criminal conspiracy in the case of conspiracy in the criminal act of corruption is also thick with the dominance of political power where in the Syahril Djohan case the perpetrator was released but in the Setya Novanto case, the perpetrator was still convicted. This is clearly contrary to the justice of Pancasila which requires a balance in the realization of human values so that justice for all groups of society can be realized properly. ${ }^{8}$

In line with the above view, Chambliss and Seidman state that any action to be taken by the role holders, implementing agencies and legislators is always within the scope of the complexities of social, cultural, economic and political forces and so on. All social forces always work together in every effort to function the applicable regulations, apply sanctions, and in all activities of implementing institutions. Finally, the role played by legal institutions and institutions is the result of the operation of various kinds of weaknesses. Then Telcot Parsons stated that in the sociological point of view, society is seen as living in a series of a unified system consisting of parts that are interconnected with each other. ${ }^{9}$ Parson's view was developed from the model of the development of organizational systems found in biology where the theory is based on the assumption that all elements must function so that society can carry out its functions properly. ${ }^{10}$

As a system, the theory places law as one of the sub-systems within a larger social system. In addition to law, there are other sub-systems that have different logics and functions. The sub-systems in question are culture, politics, and economy. Culture discusses with values that are considered noble and noble, and therefore must be maintained. This sub-system functions to maintain ideal patterns in society. Law refers to the rules as the rules of the game (rule of the game). The main function of this sub system is to coordinate and control all

\footnotetext{
${ }^{7}$ Rian Prayudi Saputra, Op., cit.

8Dafit Supriyanto Daris Warsito, "Sistem Pemidanaan Terhadap Pelaku Tindak Pidana Penyalahguna Narkotika”, Jurnal Daulat Hukum, Vol. 1. No. 1 March 2018, p. 40.

${ }^{9}$ Ragil Tri Wibowo and Akhmad Khisni, "Restorative Justice in Application for Crime Investigation on Property”, Jurnal Daulat Hukum Volume 1 No. 2 June 2018, p. 555-556.

10 Bernard Raho, SVD, Teori Sosiologi Modern, Prestasi Pustaka, Jakarta, 2007, p.48.
} 
deviations to comply with the rules of the game. Politics has to do with power and authority. The task is to utilize power and authority to achieve goals. While the economy refers to the material resources needed to support the system. The task of the economic sub-system is to carry out the adaptation function in the form of the ability to master the means and facilities for system needs. ${ }^{11}$ The four subsystems, apart from being a reality inherent in society, are simultaneously challenges that must be faced by each unit of social life. The life and death of a society is determined by the functioning or not of each sub-system according to their respective duties. To ensure that, it is the law that is tasked with managing the harmony and synergistic movement of the other three sub-systems. This is called the integration function of the law in Parsons Theory. ${ }^{12}$

\subsection{The Relevance of the Value of Legal Certainty in the Criminal Arrangement of Conspiracy in Act No. 31 of 1999 Jo. Act No. 20 of 2001}

Prior to the decision of the Constitutional Court, Article 15 of Act No. 31 of 1999 Jo. Act No. 20 of 2001 is not able to explain the types of consensus in the criminal act of corruption and does not also contain elements and procedures for carrying out acts and their explanations.

Article 15 of Act No. 31 of 1999 Jo. Act No. 20 of 2001 states that: Everyone who conducts experiments, assists, or conspires to commit a criminal act of corruption, shall be punished with the same punishment as referred to in Article 2, Article 3, Article 5 to Article 14.

Article 15 of Act No. 31 of 1999 Jo. Act No. 20 of 2001 relates to Article 53 and Article 56 of the Criminal Code. Article 53 of the Criminal Code states that:

(1) Attempting to commit a crime will be punished, if the intention for that has been proven from the beginning of the execution, and the non-completion of the execution, is not solely due to his own will.

(2) The maximum principal penalty for crimes, in the case of probation, is reduced by one third.

(3) If the crime is punishable by death or life imprisonment, a maximum imprisonment of fifteen years is imposed.

(4) The additional penalty for probation is the same as a completed crime.

Meanwhile Article 56 of the Criminal Code states clearly and unequivocally that: Convicted of being an assistant to a crime: those who intentionally provide assistance when a crime is committed; Those who deliberately provide opportunities, means or information to commit crimes.

Temporary Article 88 of the Criminal Code cannot be linked to Article 15 of the PTPK Law because Article 88 of the Criminal Code is contained in Book IX of the Criminal Code and according to Article 103 of the Criminal Code the provisions as intended in Book IX of the Criminal Code cannot be related to criminal provisions outside the Criminal Code. This is confirmed by Article 103 of the Criminal Code which reads: The provisions in Chapters I to VIII of this book also

\footnotetext{
${ }^{11 B e r n a r d ~ L . ~ T a n y a, ~ d k k . ~ T e o r i ~ H u k u m ~ S t r a t e g i ~ T e r t i b ~ M a n u s i a ~ L i n t a s ~ R u a n g ~ d a n ~ G e n e r a s i, ~ G e n t a ~}$ Publishing, Yogyakarta, 2010, p. 152.

12 Ibid.
} 
apply to acts which are punishable by other statutory provisions, unless the law provides otherwise.

So it is clear that Article 15 of the PTPK Law cannot be linked to Article 88 of the Criminal Code because Article 88 of the Criminal Code is contained in book IX of the Criminal Code while Article 103 of the Criminal Code only able to bridge the provisions of the Criminal Code with criminal provisions outside the Criminal Code only when it relates to the provisions of the Criminal Code as regulated in book I. This situation is further complicated by the absence of the element of evil conspiracy in the Anti-Corruption Law. The Constitutional Court's decision in Case Number 25/PUU-XIV/2016, the phrase "can" in Article 2 and Article 3 of the PTPK Law, then a malicious conspiracy can only be proven by proving an agreement between two or more people that has actually harmed the state's finances and economy. If these elements cannot be proven, then conspiracy in a corruption case cannot be imposed. This means that the evil conspiracy in the corruption case as regulated in the Constitutional Court's decision does not also contain elements of corruption meeting of minds. In addition, acts of conspiracy to commit crimes of corruption are combined in Article 15 as if these two types of crimes have similarities, even though it is clear that these two types of crimes have differences. The differences in question are:

- According to the Criminal Code, a probationary crime is: Attempting to commit a crime will be punished, if the intention for that has been proven from the beginning of the execution, and the non-completion of the execution, is not solely due to his own will. Meanwhile, an evil conspiracy is when two or more people have agreed to commit a crime.

- Probationary crimes are divided into two, namely, attempted crimes as stipulated in Article 53 of the Criminal Code and attempted crimes against violations stipulated in Article 54 of the Criminal Code. Meanwhile, the crime of conspiracy is only regulated in Article 88 of the Criminal Code.

- There are differences in the elements in the crime of conspiracy with trial, in the crime of probation the elements consist of an intention to commit a crime intentionally, the beginning of the implementation (Begin Van Uitvoering), and the non-completion of the act due to things beyond the control of the perpetrator of the crime. While the elements of the criminal act of conspiracy consist of the presence of two or more people, there has been an agreement to commit a crime.

\section{Closing}

The construction of evil conspiracy in corruption in Indonesia has not been able to bring about justice, this is due to the unclear elements and mechanisms of proof of evil conspiracy in Article 15 of Act No. 31 of 1999 Jo. Act No. 20 of 2001.There needs to be a setting regarding element and the notion of conspiracy in particular in the crime of corruption.

\section{References}

\section{Journal}


[1] Dafit Supriyanto Daris Warsito, "Sistem Pemidanaan Terhadap Pelaku Tindak Pidana Penyalahguna Narkotika”, Jurnal Daulat Hukum, Vol. 1. No. 1 March 2018

[2] Fatkhurohman and Nalom Kurniawan, "Pergeseran Delik Korupsi dalam Putusan Mahkamah Konstitusi Nomor 25/PUU-XIV/2016", Jurnal Konstitusi, Volume 14, Nomor 1, March 2017

[3] Ibnu Suka, Gunarto, and Umar Ma'ruf, "Peran Dan Tanggung Jawab Polri Sebagai Penegak Hukum Dalam Melaksanaan Restorative Justice Untuk Keadilan Dan Kemanfaatan Masyarakat", Jurnal Hukum Khaira Ummah Vol. 13. No. 1 March 2018

[4] Ragil Tri Wibowo and Akhmad Khisni, "Restorative Justice in Application for Crime Investigation on Property", Jurnal Daulat Hukum Volume 1 No. 2 June 2018

[5] Rian Prayudi Saputra, "Perbandingan Hukum Pidana Indonesia Dengan Inggris", Jurnal Pahlawan, Volume 3 Nomor 1 Tahun 2020

\section{Books}

[1] Abdul Aziz Dahlan, 2006, Ensiklopedia Hukum Islam 5, PT Ichtiar, Jakarta

[2] Abdul Qadir Audah, 2007, At-Tasyri, al-Jina'i al-Islamiy Muqaranan bil Qanunil Wad'iy, Kharisma Ilmu, Jilid II, Kharisma Ilmu, Bogor

[3] Anonim, 1996, Ensiklopedia Hukum Islam, Ichtiar Baru Van Hoeve, Jakarta

[4] Bernard L. Tanya, dkk. 2010, Teori Hukum Strategi Tertib Manusia Lintas Ruang dan Generasi, Genta Publishing, Yogyakarta

[5] Bernard Raho, SVD, 2007, Teori Sosiologi Modern, Prestasi Pustaka, Jakarta

[6] John Rawls, 1973,A Theory of Justice, Oxford University, London

[7] John Rawls, 2011, Teori Keadilan, Pustaka Pelajar,Yogyakarta

[8] Mohammad Daud AM., 1993, Hukum Islam Pengantar Ilmu Hukum dan Tata Hukum Islam di Indonesia, Rajawali Pers, Jakarta

[9] Sri Endah Wahyuningsih, 2013, Prinsip-Prinsip Individualisasi Pidana Dalam Hukum Islam Dan Pembaharuan Hukum Indonesia, UNDIP, Semarang

[10] Sugiono, 2009, Metode Penelitian Kuantitatif, Kualitatif dan R\&D, Alfabeta, Bandung

[11] Van Hoeve, 2002, Ensiklopedi Islam, PT Intermasa, Jakarta

[12] Wirjono Prodjodikoro, 1981, Asas Asas Hukum Pidana, Eresco, Bandung

[13] Yudi Kristiana 2018, Menyibak Kebenaran, Ekasaminai Terhadap Putusan Perkara Irman Gusman, Bumi aksara, Jakarta

\section{Internet}

[1] Amelia, Korupsi Dalam Tinjauan Hukum Islam, diakses melalui https://media.neliti.com/media/publications/270242-korupsi-dalamtinjauan-hukum-islam-f52ad996.pdf, accessed on 12 January 2020

[2] https://www.justice.gov/archives/jm/criminal-resource-manual-923-18usc-371-conspiracy-defraud-us, accessed on 10 May 2021

[3] http://repository.unair.ac.id/94028/4/4.\%20BAB\%20I\%20.pdf, accessed on 12 June 2020 
[4] katadata.co.id/berita/2019/04/29/vonis-hakim-dalam-kasus-korupsidinilai-tak-konsisten, Vonis Hakim Dalam Kasus Korupsi Dinilai Tak Konsisten, accessed on 12 January 2020

[5] thttp://www.bbc.com/indonesia/berita indonesia/2010/08/100831 anggo dovonis.shtml, accessed on 2 January 2021 